\title{
Credit Default Risk Assessment of Local Government Debts Based on KMV Model
}

\author{
Zirong Zhuo ${ }^{1}$, Jixiang Liu $^{1} \&$ Wenmin Luo ${ }^{1}$ \\ ${ }^{1}$ International Business School, Jinan University, Guangdong, China \\ Correspondence: Zirong Zhuo, International Business School, Jinan University, Guangdong, China. Tel: \\ 86-137-5005-6436. E-mail: zhuofeng101@163.com
}

Received: February 14, 2016

Accepted: March 3, 2016

Online Published: April 25, 2016

doi:10.5539/ijef.v8n5p230

URL: http://dx.doi.org/10.5539/ijef.v8n5p230

\begin{abstract}
With the continuing expansion of Chinese local government debts, its credit risk issues raise the public attention. According to the overall statistics data in Chinese Statistic Bureau, there're various scales of debts exist, undertaken by Chinese prefecture-level cities' local government. Some of them exceed the alerting level of international line. In an effort to measure the credit default risk level of Chinese local governments, this paper makes a moderate assessment of credit default risk based on modified KMV model. In conditions of a variety of local government revenue, this model calculates the distance from default and default possibility of local government debts under different guarantee proportion. Meanwhile, this paper also explores the variation of local governments' credit default risk when they use different financial ratio of financing for the construction of urban infrastructure. Finally, we reach the conclusion that the expected default probability shrinks as guarantee proportion raises, and increases as financing proportion raises; under a $40 \%$ of guarantee proportion, expected default rates are low with controllable risks; And within a financing proportion of $50 \%$, chances of default as well as risks, are low.
\end{abstract}

Keyword: local government debts, modified KMV model, credit risk, probability of default

\section{Introduction}

Ever since China's gargantuan stimulus of 2009, which was unleashed to repel the global financial crisis, there have been concerns about how the debts incurred during that spending binge would be repaid and whether it will affect the debt paying ability of Chinese government. Meanwhile, the local government debts see a tremendous scale, rapid growing pace and unreasonable structure. According to the 32nd announcement in 2013 made by China audit office, the government debts have reached the amount of 178,908.866 billion, which concluded debts government born repay obligation adding up to 108,859 .17billion, accounting for $60.85 \%$, whose yearly growing speed reached $26.83 \%$. As a result, risk issues of government debts emerge as the scales are enlarging, with some of which exceeding the international standard warning line, and containing risks of default. The revolution of tax distribution system of our country in 1994, giving rise to the unbalance between power on financial affairs and authority of office, in addition to the restriction of Budget Law, leads local government to raise money through city bonds and trust in local financing platform and result in the rapid expansion of local government debts. Afflicted by the global financial crisis in 2008, an investment stimulus of 4 trillion was raised by the central government, in which 282 million was collected from local government. As local governments receipts are relatively low and are restrained from issuing bonds freely, most of them chose to raise money from local government financing platforms to cover the gap. At the same time, under the assessment and promotion mechanism that government performances are determined by GDP, local governments financed mainly through more private channel such as local financing platform into the construction of infrastructures, which, significantly resulted in the rapid expansion of local government debts. As Several Proposals on Further Management of Local Government Debts allotted by the State Council states that, local governments are responsible for the debts they ran and central government offer no salvation, as well as ..., these increase the default risks of local governments. Meanwhile, debts crisis took place in Spain, Portugal and Greece etc. raised people's awareness across the globe of the risk of excessive debts undertaken by governments, which will increase the burden of government as well as fiscal risks and even give rise to financial crisis hurting local economy, despite the fact that appropriate loan can serve as a stimulus to the local economy. Therefore, it is an 
urgent problem to be solved that how to determine to sizes of debts, evaluate and forecast the credit risks, and take steps based on risk levels.

To estimate the credit risks of local government debts, the total amount of debts along with guarantee and financing proportion are to be considered. Most of the relative researches lack the concerns with the influence of debts factors, using KMV model to assess the default risks of local government bonds. As a result, this paper studies the aggregate levels of default risks with improved KMV model, and calculates the distance to default and expected default probabilities, so as to decide a most appropriate scale of debts as well as guarantee and financing proportion. When predicting local fiscal revenue and Residents' savings added value, linear regression is frequently applied while we use VAR model and ARMA model to predict the data from 2015, for a more precise outcome. This paper is divided into several parts: literature review, methodology, empirical evidence and conclusion.

\section{Literature Review}

Currently, many studies have been conducted on credit risks of government debts, which focus on several aspects as follows:

Primarily, study on the scale on local government debts.

Firstly, we analyze the factors which influence the debts. Lijuan Xu (2012) viewed that the unbalance between power on financial affairs and authority of office, the misconception of government function and the simplification of government administration give rise to the growth of hidden debts and contingent liabilities as well as expansion of debts and accumulation of risks. Bowen Wei and Lin Jiang (2013) raised that the constraint of local government budget, lack of incentives and influence from macroeconomic policy result in the loan expansion. Benny Geys (2016) raised that the implementation of balanced government budget is negatively related to the growth of debts. By analyzing from an aspect of public option theory, Zhongyi Li (2013) held the view that the main reasons for the increase of government expenditure is that the local authorities' behavior of raising the record, transferring risks, rent-setting and rent-seeking, analyzing from public choice theory. Runmin $\mathrm{Fu}$ (2013), however, raised that the separation of power and duties is the essential motivation of debts risks, even though economic development, financial system, management and government administration contribute the debts rise. What's more, factors of size of economy, investment, fiscal policy etc. are held by Arnaud Mehl \& Julien Reynaud (2010), who worked with the historical data of 33 emerging companies in a decade and conducted an empirical study on the government loan in the risks sources perspective. Secondly, we consider the scale of local government debts. Wang and Xiong (2011) listed three kinds of situation: optimistic, neutral and pessimistic predicated on financing platforms of different fields and categories and their yield of bad loans, and measured the scale of bad debts under those situations while Hong and Li (2015) applied Asset liability framework theory raised by Kudoki and Kumo, without considering how the maturity structure will affect the debts sizes. However, Sui and $\mathrm{Li}$ cover the defect of the theory above by taking financial revenue and expenditure of current period as well as the cost and benefit effects into dynamic and substantial analysis to assess the largest scale of loan in current period. Thirdly, we alert the risk which may be caused by swelled government debts. Zhai (2010) held the view that investment should be control to attenuate fiscal risks while Ma (2008) pointed that the solution lies in the bonding of government debts, which eventually leads to a more transparent, legal, commercialized and regulatory mechanism of local government debts.

Then, to work on the warning index of debts risks, an index system is established to monitor the liabilities of local authorities.

Zhang (2008) offered two typical alert systems, Ohio pattern and Colombia "traffic signal" system as a reference warning index. Pei and Ouyang (2015) conduct a research on the debts warning including index system construction, weighting on each index, risks measuring, risks intervals setting etc. Kao (2009) build an index system containing three segments of the procedure: borrowing, utilizing and reimbursing while Miu and Gu (2012) build a system according to the external burden and internal structure. In conclusion, basic warning indexes of local government debts consist of debts dependency and burden degree, fiscal burden degree and debts serving ratio of local government, proportion of overdue debts, guarantee debts, and new borrowing debts etc.

Ultimately, to study on risks assessment base on models, among which the most commonly used one, is KMV model. Han et al. (2003) firstly applied KMV model to city bonds risk measuring and analyzed the credit risks of debts of different sizes based on fiscal balance data of Beijing city and Shanghai city. Huang (2015) also make an analysis of default risks of governments in Yangtze River Delta region predicated on KMV model. However, $\mathrm{Ru}$ (2009) predicted the fiscal revenue of Shanghai city by autoregression and concluded that the growing trend 
of default probability slows down when is lower than $36 \%$ of the fiscal revenue. Zhou (2010) calculated the fiscal revenue of Liaoning province by multivariate linear regression model and reached the conclusion that it is relatively safe when bonds account for 15\% of the fiscal revenue. Li et al. (2013) improved the KMV model and viewed that a parent-child relationship exists between central and local government, which makes it possible to transfer the debts for local government, and so does moral risks instead of default risk of local government which is concluded based on the empirical study on the improved KMV model. Despite what has been mentioned above, a payment of loan, which accounts for $41 \%$ of local fiscal revenue was raised by Chen (2014), after analyzing panel data of 10 typical cities and provinces.

\section{Methodology}

\subsection{Government Debt Risks Assessment \& Construction of KMV Model}

KMV model, also known as Expected Default Frequency Model, predicated on the option pricing formula raised by Black Scholes and credit risk assessment model based on risk debt pricing theory, firstly confirm the expected asset value by calculating market value of company assets, then find out the default point by company liability and the default of distance from the expected asset value, and end with obtaining the mapping of default probabilities based on distance from default. When applying KMV model to the default risk issues, the basic method is the view the government borrowing as a transfer of title to the fiscal revenue from government to creditors; by the repaying principle and interest the government redeems the title of revenue; when local debts fall due and the guaranteed fiscal revenue surpass both principle and interest, government will have to repay capital with interest; the other way round, when capital and interest exceed the guaranteed part, a breach of contract occurs.

The essence of KMV model is to obtain the distance from default using relative debts scales and reimbursing abilities and its qualitative volatility, which is improved by researchers Han, Luo (2002), Ru (2009) et al. in accordance to the reality of local government loans of our country. An enhanced model measuring debt risk is as followed:

$$
D D=\frac{\ln \frac{M_{T}}{B_{T}}+\left(\mathrm{g}-\frac{\sigma_{m}{ }^{2}}{2}\right) \Delta t}{\sigma_{m} \sqrt{T}}
$$

Where DD denotes distance from default, $\Delta t$ denotes the duration of liabilities, $\Delta t=T-\mathrm{t}, t$ represents the current moment, $t=0$, thus $T=\Delta t$, and $B_{T}$ the size of loan need to be repaid, $M_{T}$ the revenue appropriated to repay debts, $\sigma_{m}$ changing rate of fiscal revenue, $g$ the growing ratio of government receipts.

Then, under the assumption that government receipts follow the log-normal distribution, we estimate the default probabilities, which can be calculated by:

$$
P=N(-D)=N\left[-\frac{\ln \frac{M_{T}}{B_{T}}+\left(\mathrm{g}-\frac{\sigma_{m}{ }^{2}}{2}\right) \Delta \mathrm{t}}{\sigma_{m} \sqrt{T}}\right]
$$

Researches shows that the fiscal revenues meet the Markov random process, thus we suppose that local fiscal revenues $M_{T}$ follows process of geometric Brownian motion, that is:

$$
d M_{T}=g M_{t} d t+\sigma_{m} M_{0} d Z_{t}
$$

Where $g$ is instantaneous growing rate of revenues; $\sigma_{m}$ is revenues fluctuation ratio, and $d M_{t}$ denotes the changing amount of revenues whilst $d Z_{t}$ is the increment of Wiener process.

Under $t=0, M_{0}=M$ and equation (3), we know that the fiscal revenue $M_{T}$ when $t>0$ equals to:

$$
M_{t}=M_{0} \exp \left\{\left(g-\frac{1}{2} \sigma_{m}^{2}\right) t+\sigma_{m} \sqrt{t} Z_{t}\right\}
$$

Where $M_{0}$ represents the current government receipts which are available to guarantee, $Z_{t} \sim N(0,1)$, and they follows the log-normal distribution.

If $F=\ln M_{t}$, then $\frac{\partial F}{\partial M_{t}}=\frac{1}{M_{t}}, \frac{\partial^{2} F}{\partial M_{t}^{2}}=-\frac{1}{M_{t}^{2}}, \frac{\partial F}{\partial t}=0$. Base on Itō's lemma, we say: 


$$
\begin{aligned}
d F= & \left(\frac{\partial F}{\partial M_{t}} g M_{t}+\frac{\partial F}{\partial t}+\frac{1}{2} \frac{\partial^{2} F}{\partial M_{t}{ }^{2}} \sigma_{m}{ }^{2} M_{t}{ }^{2}\right) d t+\frac{\partial F}{\partial M_{t}} \sigma_{m} M_{t} d z \\
= & \left(g-\frac{\sigma_{m}{ }^{2}}{2}\right) d t+\sigma_{m} d z \\
& d \operatorname{lnM}_{t}=\left(g-\frac{\sigma_{m}{ }^{2}}{2}\right) d t+\sigma_{m} d z
\end{aligned}
$$

To solve equation (6) by integral function:

$$
\begin{gathered}
\ln \mathrm{M}_{t}-\ln M_{0}=\int_{0}^{t}\left(g-\frac{\sigma_{m}{ }^{2}}{2}\right) d t+\int_{0}^{t} \sigma_{m} d z \\
\ln \mathrm{M}_{t}=\ln M_{0}+\left(g-\frac{\sigma_{m}{ }^{2}}{2}\right) t+\sigma_{m} \sqrt{t} Z_{t}
\end{gathered}
$$

Therefore, we obtain the mean value and variance of the log guarantee fiscal revenue:

$$
\begin{gathered}
E\left[\ln \mathrm{M}_{t}\right]=\ln _{0}+g t-\frac{1}{2} \sigma_{m}{ }^{2} t \\
\operatorname{Var}\left[\ln \mathrm{M}_{t}\right]=\sigma_{m}{ }^{2} t
\end{gathered}
$$

In the process of calculating, we may as well set $t=1$, meaning we evaluate the default probability of local government in a year and we get:

$$
\begin{gathered}
g=\frac{1}{n-1} \sum_{t=1}^{n-1} \frac{M_{t+1}}{M_{t}}+\frac{1}{2} \sigma_{m}{ }^{2} \\
\sigma_{m}=\sqrt{\frac{1}{n-2} \sum_{t=1}^{n-1}\left(\ln \frac{M_{t+1}}{M_{t}}-\frac{1}{n-1} \sum_{t=1}^{n-1} \ln \frac{M_{t+1}}{M_{t}}\right)^{2}}
\end{gathered}
$$

Therefrom, we attain the Expected Default Frequency (EDF) by improved KMV model:

$$
\begin{aligned}
p & =P\left[\mathrm{M}_{t}<\mathrm{B}_{T}\right]=\mathrm{P}\left[\ln \mathrm{M}_{t}<\ln \mathrm{B}_{T}\right] \\
& =\mathrm{P}\left[\ln \mathrm{M}_{0}+\left(g-\frac{\sigma_{m}^{2}}{2}\right) \mathrm{t}+\sigma_{m} \sqrt{t} \mathrm{Z}_{t}<\ln \mathrm{B}_{T}\right] \\
& =\left[-\frac{\ln \frac{M_{0}}{B_{T}}+\left(g-\frac{\sigma_{m}{ }^{2}}{2}\right) t}{\sigma_{m} \sqrt{t}}>Z_{t}\right]
\end{aligned}
$$

As $Z_{t} \sim N(0,1)$, a normal distribution version of equation (9) is:

$$
\begin{array}{r}
\mathrm{p}=N\left[-\frac{\ln \frac{M_{0}}{B_{T}}+\left(g-\frac{\sigma_{m}{ }^{2}}{2}\right) t}{\sigma_{m} \sqrt{t}}\right] \\
D D=\frac{\ln \frac{M_{0}}{B_{T}}+\left(g-\frac{\sigma_{m}{ }^{2}}{2}\right) t}{\sigma_{m} \sqrt{t}}
\end{array}
$$

Accordingly, the expected default probability $\mathrm{p}$ is denoted as:

\subsection{Transferability and Transferring Route}

$$
p=N(-D D)=1-N(D D)
$$

The essence of credit risk is default risk, which must correspond to specific economic agents. Specific economic agents default includes two kinds of situations: one is conscious subjective defaults, or the intentional defaults, which has nothing to do with the solvency of the debtor; the other is unconscious objective default, which is caused by lack of objective solvency and thus a default occurs instead of desiring to not to repay debts. Credit risk evaluation is mainly for the latter. However, whether the latter kind of economic agents will ever breach, in addition to his own ability to repay, another important factor is that whether his debt may transfer to a third 
person who is capable of repaying. If this shift can be done, then, not only the obligor's ability to repay the debt but also the transferability should be taken into account of risk assessment.

Unlike democracy government of western developed countries, our country has a very close tie between the central government and local government. Although the implementation of the system in China formally endows economic independence with both central government and local authorities, when the local governments are trapped with debts, and are unable to repay, central government will have to "rescue", to repay the debts of local government.

Therefore, under the premise that the local government will be able to shift their loan to central government, even if local government debts are out of control and trigger a debt crisis, central government's strong interference would also ensure local government to prevent a debts default, the automatic transfer mechanism of which, is ensured by specific political and economic system of our country. Thus, when debt default risks occur, the transfer mechanism will be triggered.

The transferability of local government debt enables the central government to start the transfer procedures when a default is around the corner, and to resolve the risk. According to the research of the domestic scholars Li et al. (2013), due to the relative independence in terms of the people's bank of China to the central government, that is to say, in our country, the issue of currency and creation rights actually lies in central government rather than the central bank. The independence of Central bank determines that the central government is able to monetize the debt freely, and transfer local government debts by "seigniorage" to solve the problem. As the ultimate recipient of seigniorage is residents, it means that the debts that central government shoulder, from local government eventually divert to the residents. Assume a situation that people are able to withstand the highest seigniorage corresponds to the zero wealth added, then the largest solvency of central government through raising seigniorage which is used for local government debts shift equals to the additional residents' savings.

Having considered the factor of transferability, we can update the debts assessing KMV model as well as the default distance:

$$
D D=\frac{\ln \frac{M_{t}+q S}{B_{T}}+\left(g-\frac{\sigma_{m}{ }^{2}}{2}\right) \Delta t+\left(g_{s}-\frac{\sigma_{s}{ }^{2}}{2}\right) \Delta t}{\left(\sigma_{m}+\sigma_{s}\right) \sqrt{T}}
$$

Where $\mathrm{q}$ is the transfer ratio, representing the proportion of debts shift to the central government among the solvency of local authorities; s is additional residents' saving; $g_{s}$ and $\sigma_{s}$ are the growth rate and volatility, or standard diviation, of s respectively aforementioned. By adding up the transfer factor, the updated default probability is:

$$
P=N(-D D)=N\left[\frac{\ln \frac{M_{t}+q S}{B_{T}}+\left(g-\frac{\sigma_{m}{ }^{2}}{2}\right) \Delta t+\left(g_{s}-\frac{\sigma_{s}{ }^{2}}{2}\right) \Delta t}{\left(\sigma_{m}+\sigma_{s}\right) \sqrt{T}}\right]
$$

Meanwhile, the equations of relative variables are:

$$
\begin{gathered}
g_{s}=\frac{1}{n-1} \sum_{t=1}^{n-1} \ln \frac{S_{t+1}}{S_{t}}+\frac{1}{2} \sigma_{s}^{2} \\
\sigma_{s}=\sqrt{\frac{1}{n-2} \sum_{t=1}^{n-1}\left(\ln \frac{S_{t+1}}{S_{t}}-\frac{1}{n-1} \sum_{1}^{n-1} \frac{S_{t+1}}{S_{t}}\right)^{2}}
\end{gathered}
$$

\section{An Empirical Study on Guangdong Province}

This paper takes Guangdong province as the research object, using the local government debt credit risk assessment model mentioned above to measure the credit risk of local government debt of Guangdong province. Base on the public debt audit results of local government of Guangdong province and the financing proportion of the total amount of investment in infrastructure, we calculate a range of government default probabilities under different levels of debt sizes, associating the credit risk with sizes of borrowing. By demarcate of the probability of default, a moderate scale of local government debts of Guangdong province is put forward.

The study select the fiscal revenue and gross regional GDP data from 1994-2014 of Guangdong province, the 
source of which is Guangdong statistical yearbook of statistics. At the same time, this study assumes that the length of time of the expected default probability is for 1 year, that is predicting the probability of default of the year 2015.

\subsection{Calculation of Key Parameters}

\subsubsection{Fiscal Revenue (FR) Predicted by VAR Model}

Due to the fact that regional gross domestic product (GDP) and fiscal revenue (FR) are time series data, and only when two variables remain smooth or data co-integration, VAR model can be established, so this article first carries on the preliminary tranquilization processing of time series data, namely conducting logarithmic operation to the GDP and FR. Then, we conduct the ADF unit root test of whether data are unit root, if there is a unit root, it proved that the data are not smooth, so the phenomenon of spurious regression may exists, therefore E-G method are applied to test the co-integration. Firstly, we conduct unit root test to both lnGDP and lnFR, to examine whether the two met with the whole order list, results of which are as follows:

Table 1. ADF unit root examination

\begin{tabular}{cllllcc}
\hline Variables & Testing method & ADF stats & $5 \%$ Critical value & $10 \%$ Critical value & Prob. & Conclusion \\
\hline $\ln G D P$ & $(1,1,4)$ & -2.6389 & -3.7332 & -3.3104 & 0.2357 & instable \\
$\ln F R$ & $(1,1,0)$ & -1.5624 & -3.65845 & -3.2690 & 0.8613 & instable \\
$D(\operatorname{Ln} G D P)$ & $(1,0,2)$ & -2.6891 & -3.0522 & -2.6666 & 0.0563 & stable \\
$D(\ln F R)$ & $(1,1,0)$ & -8.3847 & -3.6736 & -3.2774 & 0.0000 & stable \\
\hline
\end{tabular}

From the point of unit root test, the significant probabilities of original sequence ADF $\operatorname{lnGDP}$ and $\ln$ FR stats were greater than 0.05 , and accept the null hypothesis on the 5\% significance level, that there are unit roots, which means non-stationary; If significant probability of the first-order difference sequence of ADF statistic of lnGDP is less than 0.10 , we can reject the null hypothesis under the $10 \%$ significance level and there is no unit root, and is smooth; if the first order difference sequence of lnFR ADF statistic significant probability is less than 0.05 , we reject the null hypothesis under the 5\% significance level that there is no unit root, and is smooth. That is to say, the GDP and FR variables are a single whole. Then we conduct regression to the two variables for regression and obtain the residuals $e_{t}$, after that, we conduct unit root test without intercept and trend, the results of which are as follows:

Table 2. Unit root examination of residuals

\begin{tabular}{ccccccc}
\hline variables & Examination method & ADF stats & $5 \%$ critical value & $10 \%$ critical value & Prob. & Conclusion \\
\hline$e_{+}$ & $(0,0,0)$ & -3.1751 & -1.9591 & -1.6075 & 0.0018 & Stationary \\
\hline
\end{tabular}

From the results, the residual items meet smooth sequence, which illustrates the relationship between two variables is co-integrated, thus it is suitable for the setup of VAR model. Before the construction of VAR model, confirmation of the lag order of the two variables is required, and the inspection results are as follows:

Table 3. Inspection results of lag periods in VAR model

\begin{tabular}{cclllll}
\hline Lag & LogL & \multicolumn{1}{c}{ LR } & \multicolumn{1}{c}{ FPE } & \multicolumn{1}{c}{ AIC } & SC & HQ \\
\hline 0 & 66.54146 & NA & $6.07 \mathrm{E}-05$ & -4.033841 & -3.942233 & -4.003475 \\
1 & 75.28297 & $15.84400^{*}$ & $4.52 \mathrm{e}-05^{*}$ & $-4.330186^{*}$ & $-4.055360^{*}$ & $-4.239089^{*}$ \\
2 & 77.32426 & 3.444677 & $5.13 \mathrm{E}-05$ & -4.207766 & -3.749724 & -4.055938 \\
3 & 80.30913 & 4.663857 & $5.51 \mathrm{E}-05$ & -4.144321 & -3.503061 & -3.931761 \\
4 & 83.17354 & 4.117589 & $6.02 \mathrm{E}-05$ & -4.073346 & -3.24887 & -3.800056 \\
\hline
\end{tabular}

We take the best lag period as first-order lag order predicated on various statistics, and build the VAR(1) model of first-order lag:

$$
\left[\begin{array}{c}
\mathrm{D} \ln F R_{\mathrm{t}} \\
\mathrm{D} \ln G D P_{t}
\end{array}\right]=\left[\begin{array}{c}
c_{1} \\
c_{2}
\end{array}\right]+\left[\begin{array}{ll}
b_{11} & b_{12} \\
b_{21} & b_{22}
\end{array}\right]\left[\begin{array}{c}
\mathrm{D} \ln F R_{\mathrm{t}-1} \\
\mathrm{D} \ln G D P_{t-1}
\end{array}\right]+\left[\begin{array}{c}
\varepsilon_{1} \\
\varepsilon_{2}
\end{array}\right]
$$


Where the matrix $\left[\begin{array}{ll}b_{11} & b_{12} \\ b_{21} & b_{22}\end{array}\right]\left[\begin{array}{c}\ln F R_{\mathrm{t}-1} \\ \ln G D P_{t-1}\end{array}\right]$ represents the influence of endogenous variables lag one period; the matrix $\left[\begin{array}{l}\varepsilon_{1} \\ \varepsilon_{2}\end{array}\right]$ represents the stochastic disturbances, meeting the mean to 0 , variance of 1 white noise process.

After regression by Eviews we have:

$$
\left[\begin{array}{c}
\mathrm{D} \ln F R_{\mathrm{t}} \\
\mathrm{D} \ln G D P_{t}
\end{array}\right]=\left[\begin{array}{c}
0.2128 \\
0.0549
\end{array}\right]+\left[\begin{array}{cc}
0.1166 & -0.4138 \\
-0.0615 & 0.6996
\end{array}\right]\left[\begin{array}{c}
\mathrm{D} \ln F R_{\mathrm{t}-1} \\
\mathrm{D} \ln G D P_{t-1}
\end{array}\right]
$$

And we conduct motion prediction to the $\operatorname{lnFR}$ in 2015 and in a natural logarithm to calculate the value of the local fiscal revenue FR, finally obtained to predicted local fiscal revenue in 2015 in Guangdong province, which is 894.667 billion.

As a large part of the local fiscal income is used for public services, education, social security and medical and health care and other necessary expenses, only part of which can be appropriate to repay the debts of local government as guarantee income $M_{t}$. In term of the guarantee proportion, there is no unified conclusion as different researchers hold different views. Thus, this paper use a series of guarantee ratio, $10 \%, 20 \%, \ldots, 100 \%$, and the corresponding guarantee fiscal income, calculating the default distances and expected default probabilities, in attempt to measure the credit risks status and trends of local government.

Table 4. Fiscal income under various guarantee ratio

\begin{tabular}{ccccccccccc}
\hline$\tau$ & $10 \%$ & $20 \%$ & $30 \%$ & $40 \%$ & $50 \%$ & $60 \%$ & $70 \%$ & $80 \%$ & $90 \%$ & $100 \%$ \\
\hline$M_{t}$ & 894.66 & 1789.33 & 2684 & 3578.67 & 4473.34 & 5368 & 6262.67 & 7157.34 & 8052 & 8946.67 \\
\hline
\end{tabular}

From equation (11) and (12) we know, different guarantee rate have no impact on the growth rate $\mathrm{g}$ and volatility $\sigma_{m}$ of local fiscal income. Hence we bring the calculated $M_{t}$ in the equation (11) and (12), obtaining $\mathrm{g}=0.17765, \sigma_{m}=0.15715$, and the final parameters are as follow:

Table 5. Part of the key parameters

\begin{tabular}{llccc}
\hline Years & $\ln F R$ & $F R$ & $g$ & $\sigma_{m}$ \\
\hline 2015 & 9.09903 & 8946.67 & 0.17765 & 0.15715 \\
\hline
\end{tabular}

\subsubsection{The Additional Residents' Saving Predicted by ARMA Model}

ARMA model is used to predict the stability of the variable $S$ after taking the logarithm smoothing treatment. If it can satisfy the stationary sequence, the prediction of the model can be established. Firstly, $\ln S$ is tested for stability:

Table 6. Unit root test of $\ln S$

\begin{tabular}{ccccccc}
\hline Variable & Testing method & ADF stats & $5 \%$ Critical value & $10 \%$ Critical value & Probability & Conclusion \\
\hline $\ln S$ & $(1,1,0)$ & -4.3127 & -3.6736 & -3.2773 & 0.0253 & Stable \\
\hline
\end{tabular}

The significance probability of ADF statistic of less than 0.05 , indicating that a unit root does not exist in the sequence and the sequence is a stationary series. After inspection that the autocorrelation tailing, partial autocorrelation first-order truncation, thus according to AIC and SC criterion, the establishment of model is as follows:

And the regression results:

$$
\ln S_{t}=a_{0}+a_{1} \ln S_{t-1}+\mu_{t}
$$

Table 7. Regression results of model

\begin{tabular}{ccccc}
\hline Variable & Coefficient & Std.Error & t-Statistic & Prob. \\
\hline $\mathrm{C}$ & 18.1454 & 1.5147 & 5.63614 & 0.0000 \\
$\mathrm{AR}(1)$ & 0.7615 & 0.0841 & 8.2145 & 0.0000 \\
$R^{2}$ & \multicolumn{5}{c}{0.8392} \\
\hline \multicolumn{5}{c}{}
\end{tabular}


In which, the $\mathrm{T}$ test significance probability of $\mathrm{AR}(1)$ is less than 0.05 and pass the $\mathrm{T}$ test under a significance level of $5 \%$. Relative high $R^{2}$ indicate that the interpretation degree of model is preferable. Then by backstepping algorithm in the natural logarithm of $\operatorname{lnS}$, and bring the result s to formula (20), obtaining $\sigma_{s}$ and combining (19), the overall results are these:

Table 8. Prediction of relative parameters

\begin{tabular}{ccccc}
\hline Year & $\operatorname{lnS}$ & $\mathrm{S}$ & $g_{s}$ & $\sigma_{s}$ \\
\hline 2015 & 8.4925 & 4878.04 & 0.1714 & 0.3251 \\
\hline
\end{tabular}

\subsubsection{Calculation of $B_{T}$}

According to the government born liability of Guangdong Province in 2015 announced in 2013 by Guangdong Provincial Audit Department, which amounted to 1037.22 billion and the amount of government or total debt (including the debts government bears the responsibility for guarantee and for relief) amounted to 667.115 billion. Total debt of local government $=$ Debts bearing repayment responsibility + contingent debt $*$ certain proportion. As for the proportion of contingent debt, this paper refers to the experience of previous studies, select the proportion of $25 \%$ as repayment ratio of contingent debt, so Guangdong Province in 2015 total debt of local government:

$$
B_{T}=1037.22+667.115 \times 25 \%=1203.99 \text { billion }
$$

\subsection{KMV Risk Assessment Under a Variety of Guarantee Ratio}

Base on KMV model, we bring the numerical value of parameters aforementioned, $g, \sigma_{m}, B_{T}, \mathrm{~g}_{\mathrm{s}}, \sigma_{\mathrm{s}}$ and the guarantee fiscal income value $M_{t}$, under different guarantee ratio to the default distance formula (17) and expected default probability formula (18). Taking 2014 as the base year, T equals to1 in the year2015 and referring to the previous scholar experience, assuming that the undertaking ability of central government, $\mathrm{q}$, is 0.1 , we can calculate by Matlab, under different proportion of contingent liability, the default distance and expected default probability:

Table 9. Default occurred in 2015 under different guarantee ratio

\begin{tabular}{|c|c|c|c|}
\hline Proportion & Fiscal income $M_{t}$ & Default distance (DD) & Expected default probability (EDP) \\
\hline $10 \%$ & 894.67 & 0.722 & $23.503 \%$ \\
\hline $20 \%$ & 1789.33 & 1.129 & $12.941 \%$ \\
\hline $30 \%$ & 2684.00 & 1.558 & $5.962 \%$ \\
\hline $40 \%$ & 3578.67 & 3.551 & 0.0019 \\
\hline $50 \%$ & 4473.34 & 4.774 & 0.0000 \\
\hline $60 \%$ & 5368.00 & 6.220 & 0.0000 \\
\hline $70 \%$ & 6262.67 & 7.989 & 0.0000 \\
\hline $80 \%$ & 7157.34 & 10.271 & 0.0000 \\
\hline $90 \%$ & 8052.00 & 13.487 & 0.0000 \\
\hline $100 \%$ & 8946.67 & 18.984 & 0.0000 \\
\hline
\end{tabular}

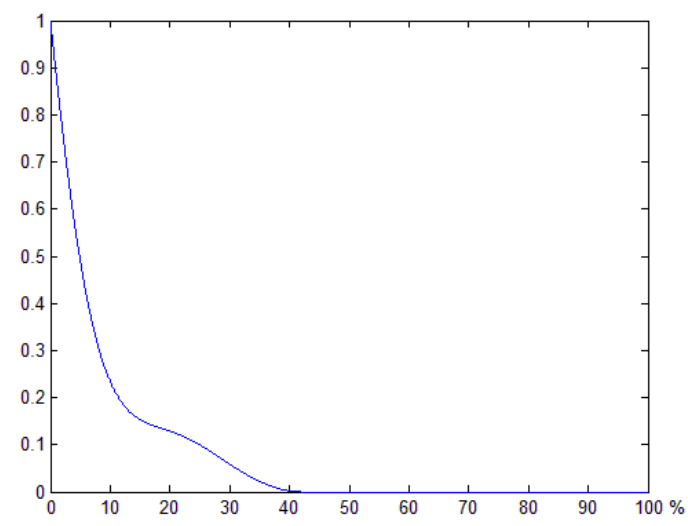

Figure 1. Varying curve of EDF under different guarantee ratio 
From the result we conclude, as the guarantee ratio increases, the EDF curve sees a down trend, and when the guarantee ratio reaches $40 \%$, the expected default probability is extremely low, down to 0 . Therefore, the aggregate debt risk is controllable with relatively low default probability.

\subsection{KMv Risk Assessment under Different Financing Proportion}

From the investments that local government made, they are mainly for infrastructure construction, which are guaranteed by local government in the name of government security and consist of the local government debts. Therefore, this paper assumes that the infrastructure construction funds of Guangdong Province in 2015 wholly or partly come from the financing of local government base on different financing proportion of $10 \%, 20 \%$, $30 \% \ldots$ We set the size of local government debt and study under different proportion of financing, local government default distance and the expected default probability, in order to analyze optimal government financing ratio, and determine the appropriate local government debt scale.

According to the Guangdong Provincial Bureau of statistics data, the 2014 Guangdong Province infrastructure construction investment amounted to 5984.42 billion, and under the current lending rate over the period of five years of $6.39 \%$, we obtain the capital and interest of various scales that government borrowed for infrastructure investment in 2014, as local government debt $B_{t}$ in KMV model and under the assumption of a guarantee proportion of 50\% from the equation (17) and (18), we bring a range of $B_{t}$ under different financing ratio to the calculation of default distance and expected default probability, the results of which are in following table:

Table 10. Default distance and expected default probability under different financing proportion (Unit: million)

\begin{tabular}{ccccc}
\hline Financing proportion & Financing amount & Capital and interest $B_{t}$ & DD & EDF $(\%)$ \\
\hline $10 \%$ & 59844 & 63674.02 & 1943.7 & 0 \\
$20 \%$ & 119688 & 127348 & 1751.3 & 0 \\
$30 \%$ & 179533 & 191023.1 & 1092.8 & 0 \\
$40 \%$ & 239377 & 254697.1 & 587.9 & 0 \\
$50 \%$ & 299221 & 318371.1 & 430.1 & 092.71 \\
$60 \%$ & 359065 & 382045.2 & 246.6 & 756.58 \\
$70 \%$ & 418909 & 445719.2 & 102.1 & 1536.71 \\
$80 \%$ & 478754 & 509394.3 & -27.1 & 5759.25 \\
$90 \%$ & 538598 & 573068.3 & -143.5 & 9215.63 \\
$100 \%$ & 598442 & 636742.3 & -279.3 & 9914.54 \\
\hline
\end{tabular}

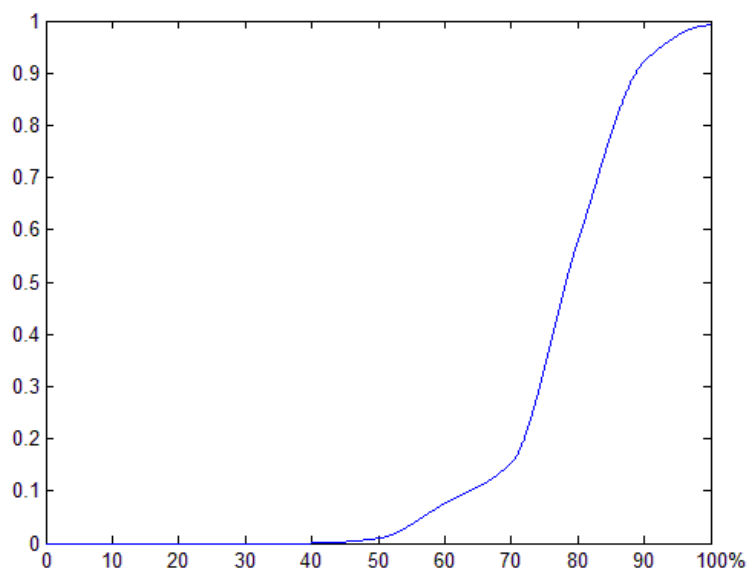

Figure 2. EDF curve under different financing proportion

It can be seen from the results that, the expected default probability curve of local government debt shows a rising trend with the increase in the proportion of financing, while local governments appropriate the funds in infrastructure construction lower than $50 \%$ of the total debts, i.e. borrowing less than 2992.21 billion, the expected default probability of government debt is extremely low, closing to 0 ; However, when the financing ratio exceeds $50 \%$, expected default probability presents a nonlinear trend of accelerated growth, and with the expansion of the scale of debt, especially when financing ratio increase to $90 \%$, expected default probabilities 
increase by more than $92 \%$. At this time, the default risk is very high.

\section{Conclusion}

The paper study on the China local government debt credit risk by using the modified KMV model and by taking Guangdong Province as an example, calculate the local government debt default distance and expected default probability. Results show that overall risk of Guangdong province local government debt is controllable with relatively low expected default probability, and when the proportion of local fiscal revenue can be guaranteed the above $40 \%$, the expected default probability reaches almost 0 with rather low risk of default. As the proportion of local government debt guarantee decreases, the expected default probability increases gradually while under $10 \%$ of the guarantee proportion of risk, the expected default probability is only $23.503 \%$. Therefore, the overall debt credit risk level of the local government in Guangdong Province in 2015 is low, so does the probability of default. At the same time, we see that the guarantee proportion of local government revenue should be best maintained at around $40 \%$, which basically excludes default risk. On the other hand, the credit risk of local government debt has a strong sensitivity of debt scale, and financing proportion of the amount of investment in infrastructure construction have rather great impact to the volatility of default risk as expected default probability increasing with the rising of the proportion of financing. Hence strict control of local government debt scale and reduction to the proportion of infrastructure construction financing ratio to a level lower than $50 \%$, can effectively diminish local government debt credit default risk of Guangdong Province.

\section{Acknowledgements}

This work was supported by the special fund of Guangdong College Student's Science and Technology Innovation Program (No. 139938) and National Undergraduate Training Program for Innovation and Entrepreneurship (No. 201510559062).

\section{References}

Bowen, W., \& Lin, J. (2013). Research on local government debt scale based on the net asset value. Credit Reference, (3), 86-89.

Bozic, V., \& Magazzino, C. (2013). Credit rating agencies: The importance of fundamentals in the assessment of $\begin{array}{lllll}\text { sovereign } & \text { ratings.Economic Analysis } \& \text { Policy, } & \text { 43(2), }\end{array}$ http://dx.doi.org/10.1016/S0313-5926(13)50016-6

Chen, Q. (2014). China's local government debt risk evaluation based on KMV model. Xiamen University.

Dangchen, S., \& Pan L. (2013). The research of local government debt problem in China_—Based on analysis of the dynamic sustainability under the perspective of financial risk. Journal of Yunnan University of Finance and Economics, (5), 17-25.

Degong, M., \& Minjie, M. (2015). An empirical analysis of local government debt risk control mechanism—A case study of local government debt risk assessment in sichuan province based on KMV model. Journal of Southwest University for Nationalities(Humanities and Social Science), 2, 139-144.

Fei, W., \& Peng, X. (2011). The present situation and the risk of local financing platform in China: Scale calculation and situation simulation. China Economic Studies, (1), 44-52.

Geys, B. (2016). Looking across Borders: A Test of Spatial Policy Interdependence Using Local Government Efficiency Ratings. Social Science Electronic Publishing, 60(3), 443-462.

Haitao, M. (2012). The fundamental way to solve the problem of local government debt is bond. Economic Survey, (2), 4-5.

Lasheng, L., Xiaoyuan, G., \& Jie, Z. (2013). The local government debt risk assessment in China. Statistical Research, 30(10), 30-39.

Lijuan, X. (2012). The management international experience and enlightenment of local government debt. China Finance, (18), 73-74.

Liyan, H., Chenli, Z., \& Wen, L. (2003). The research on the inssuance scale and credit risk of municipal bond of China. Financial Research, (2).

Mehl, A., \& Reynaud, J. (2010). Risky public domestic debt composition in emerging economies. Journal of International Money \& Finance, 29(1), 1-18. http://dx.doi.org/10.1016/j.jimonfin.2009.02.003

Peng, Z. (2010). Local government bond issuance risk assessment. Modern Management Science, (12), 77-79.

Runmin, F., Xiaolin, L., \& Min, W. (2013). Security monitoring and early warning mechanism of public finance 
in China - A theoretical research framework. Finance \& Trade Economics, 34(8), 18-26.

Shinan, C., \& Xiao, L. (2013). The countermeasures and suggestions to resolve the local government debt. Macroeconomic Management, (7), 40-41.

Tao, R. (2009). The credit risk measurement and financing scale research in the process of local government bonds issuance. Fudan University.

Xiaolin, L., \& Runmin, F. (2012). China's local government debt risk to measure and generated data research_B Based on the experience of the western province. Finance \& Trade Economics, (1), 17-24.

Xuekai, W., \& Ruiling, H. (2015). Local government debt default risk analysis based on KMV model - A Case Study of the Yangtze-Delta Region. Shanghai Journal of Economics, 04, 62-69.

Yanmin, Z. (2010). Control the scale of investment in the government financing to prevent financial risks. Macroeconomic Management, (3), 53-54.

Yanming, K., Shumei, W., \& Jingting, M. (2009). The research on the construction and evaluation model of performance evaluation index system on local government debt. Contemporary Finance \& Economics, (7), 34-38.

Yu, P. (2015). Ouyang Huasheng. China's local government debt risk early warning theory analysis. China Soft Science, (3), 110-114.

Yuan, H., \& Li, L. (2006). A comprehensive analysis of China's local government debt sustainability framework. Finance \& Economics, (4), 96-103.

Yun, W. (2015). Modern guangdong province local government debt and enlightenment. Social Scientist, 2 , 142-146.

Zhihua, Z., Ya, Z., \& Lifeng, Y. (2008). Foreign local government debt scale control and risk early warning. Review of Economic Research, (22), 8-10.

Zhongyi, L. (2013). The analysis of the causes of rapid growth of local government debt—Based on the theory of public choice perspective. Economic Vision, (5), 56-57.

Zirong, Z. (2015). Local government debt risk research in China_-From the perspective of the balance sheet. The Theory and Practice of Finance and Economics, 1, 95-99.

\section{Copyrights}

Copyright for this article is retained by the author(s), with first publication rights granted to the journal.

This is an open-access article distributed under the terms and conditions of the Creative Commons Attribution license (http://creativecommons.org/licenses/by/3.0/). 